\title{
Lithium isotopes in groundwater from distinct interconnected aquifers
}

\author{
THAÍS DE PAULA MARTELETO', MARGARETH SUGANO \\ NAVARRO $^{2}$, GUSTAVO MACEDO PAULA-SANTOS ${ }^{3}$ AND \\ JACINTA ENZWEILER ${ }^{4}$ \\ ${ }_{12,3,}$ University of Campinas / UNICAMP, Institute of \\ Geosciences, Rua Carlos Gomes 250, CEP 13083855, \\ Campinas, SP, Brazil \\ 1thais.paula@ige.unicamp.br; ${ }^{2}$ msugano@unicamp.br; \\ 33ustavomps@yahoo.com.br; ${ }^{4}$ jacintae@unicamp.br
}

The relative variability of the $\mathrm{Li}$ isotopes ratios in various geological matrices is a powerful proxy to investigate continental silicate weathering, climate change through geological time and hydrogeological processes. However, the processes controlling the $\mathrm{Li}$ isotopes fractionation in the aquatic media after the dissolution of primary minerals are not fully understood yet. Concerning the $\mathrm{Li}$ isotope signatures in groundwater, can they reveal water-rock interaction processes and provide links between the water composition and the source rocks?

Here we report the lithium isotope data measured in groundwater samples from three distinct and possibly interconnected aquifer systems located in Southeast Brazil. The study area, restricted to about $3.5 \mathrm{~km}^{2}$, has a complex local hydrogeological setting, comprising three aquifer systems. Two are crystalline aquifer systems, one with a granite-gneissic composition and the second with basic intrusive rocks of the Serra Geral Formation. The third is a sedimentary aquifer system related to the Paraná Sedimentary Basin. Fifteen groundwater samples collected within approximately six months from four tubular wells ( 200 $\mathrm{m}$ depth) presented $\mathrm{Li}$ concentrations ranging from 8.78 to $16.7 \mu \mathrm{g} \cdot \mathrm{L}^{-1}$ with a median value of $11.6 \mu \mathrm{g} \cdot \mathrm{L} \cdot$. The $\mathrm{Li}$ isotope signatures varied from $\delta \mathrm{Li}=+2.1$ to $+13.4 \%$, with a median value $\delta / \mathrm{Li}=+7.9 \%$. Such relatively high [Li] and low $\delta \mathrm{Li}$, as well as the positive correlation $\left(\mathrm{r}^{2}=0.56\right)$ between them, suggests that the released $\mathrm{Li}$ from the primary rocks is still mostly present in the groundwater and available for retention by secondary mineral phases. Other chemical constituents (among them $[\mathrm{Mg}]$ and $[\mathrm{Na}]$ ) suggest that diabase weathering contributes more to the groundwater composition extracted in two of the four wells. Some seasonal variability in several parameters, including the $\delta \mathrm{Li}$ values, suggests that flows within the three aquifer systems favor the groundwater mixing. 